УДК 655.326.1+655.3.062

() О. П. Шостачук, асистент, КПІ ім. Ігоря Сікорського, Київ, Україна

\title{
ПОКАЗНИКИ ЯКОСТІ \\ ФЛЕКСОГРАФІЧНИХ АРКУШЕВИХ МАШИН ДЛЯ ЗАДРУКОВУВАННЯ ГОФРОВАНОГО КАРТОНУ
}

\begin{abstract}
Розглядаються показники якості флексографічних машин для задруковування гофрованого картону. Проаналізовано вплив факторів, від яких залежить якість кінцевої продукції.
\end{abstract}

Ключові слова: флексографічна машина; друкарський апарат; гофрований картон; фотополімерна форма; плашка; анілоксовий вал.

\section{Постановка проблеми}

Флексографічний друк є одним із найбільш широко використовуваним у сучасному поліграфічному виробництві. За допомогою флексографічного друку задруковують гнучке паковання із поліетиленової та поліпропіленової плівки, гофрованого картону, фольги. Це обумовлене такими особливостями даного способу друку, як швидкість, економічність, порівняно невисока вартість обладнання. У зв'язку із сучасною тенденцією зростання вимог замовників до якості продукції актуальним є питання забезпечення відповідності виготовлюваної друкованої продукції найвищим стандартам якості.

Технологічні властивості поліграфічного обладнання характеризуються показниками призначення, які визначають його технологічні можливості, а також функціональними показниками, до яких відносять параметри технологічного процесу та особливості його проходження. Для аркушевих флексографічних друкарських машин для друку на гофрованому картоні технологічні можливості розкриваються через тип і параметри вихідної продукції, характери витратних матеріалів. В свою чергу вони можуть впливати не тільки на параметри технологічного процесу, але і визначають технологічну схему роботи машини та її складових частин.

\section{Аналіз попередніх досліджень}

Показники якості поліграфічного обладнання характеризують ступінь виявлення визначеної експлуатаційної властивості [1], а його найменування визначає властивості, що характеризуються, а числове значення може визначатися як в розмірних одиницях, так і в безрозмірних. Тобто кожен вид продукції характеризує своя номенклатура показників якості, яка залежить від призначення продукції. Для поліграфічного обладнання був розроблений

() $2019 p$. 
ГОСТ 4353-90 [2], який встановлював показники залежно від підгруп поліграфічного обладнання за галузевим класифікатором. У зв'язку зі значними змінами в технології поліграфічного виробництва та, відповідно з вимогами до функціонування обладнання ГОСТ не містить сучасної інформації за показниками якості та носить суто інформаційний та рекомендований характер.

\section{Мета роботи}

Метою даної роботи була систематизація показників якості друкарського обладнання, а саме аркушевих флексографічних машин, що впливають на якість вихідної продукції, аналіз факторів, що саме впливають на технологічний процес друку на гофрованому картоні.

\section{Результати проведених досліджень}

В даному дослідженні було проведено систематизацію факторів впливу на технологічні властивості флексографічної друкарської машини.

У відповідності із визначенням гОСТу 15467 [1] поняття «якість продукції», в тому числі і для машинобудівної продукції, охоплює сукупність її властивостей, які визначають ступінь придатності виконувати поставлені задачі залежно від її призначення. Стосовно технологічного обладнання для поліграфічних виробів та паковання якість визначають придатністю машин виробляти продукцію заданого накладу і якості при мінімальних витратах. Тому поліграфічне обладнання залежно від його функціонального призначення може мати велику кількість різноманітних властивостей. Проте для кожного виду поліграфічне обладнання можна класифікувати експлуатаційні властивості на три групи. До них слід віднести технологічні та технічні властивості, які дають можливість дати оцінку технічного стану поліграфічного обладнання, його складових частин, а також техніко-експлуатаційні, які надають можливість ефективного використання та ступеню придатності машини стабільно випускати якісну продукцію при вже прийнятій системі технічного обслуговування та ремонту. Якість поліграфічного обладнання залежить також від якості складових частин та матеріалів, тобто від сукупності властивостей комплектуючих, функціональних вузлів та деталей [3].

Кількісна характеристика одного або декількох властивостей, що розглядається відповідно до визначених умов її експлуатації, називається показником якості продукції. Їх розділяють на дві підгрупи:

- ознака показника якості, яка $€$ якісною або кількісною характеристикою властивості;

- параметр показника якості, який кількісно характеризує властивості або стан поліграфічного обладнання.

Показники якості для різних типів машин специфічні і залежать від їх функціонального призначення [4]. Вони описуються у відповідних нормативних документах (стандартах, технічних вимогах і т.п.) із зазначенням допустимих значень. В експлуатаційній документації вказують технічні дані, параметри і характеристики, необхідні для вивчення 
і вірної експлуатації машини та її складових частин, ГОСТ 2601 [5].

У складних системах та машинах вимоги до номенклатури показників та їх значень встановлюються як до машини (або лінії) в цілому, так і до її окремих частин, вузлів та агрегатів. При цьому значення вихідних параметрів машини залежать від параметрів, які характеризують стан їх окремих частин та вузлів, а також від їх ролі при забезпеченні запрограмованих показників якості машини в цілому. На рис. 1 наведено систематизацію показників якості флексографічного обладнання.

Було встановлено, що якість друку на гофрованому картоні суттєво залежить від:

- характеристик друкарського апарату, а саме жорсткості і точності конструкції циліндрів та елементів приводу, чутливості та стабільності їх до налагодження;

- фізико-механічних властивостей гофрованого картону та фотополімерних форм.

Аналіз конструкції і технічного рівня флексографічного обладнання для обробки гофрованого картону дозволяє зробити висновки про тенденції його розвитку:

- друкарські апарати флексографічного способу друку для гофрованого картону побудовані за двома технологічними схемами, що обумовлює різницю в експлуатації та технічному обслуговуванні;

- удосконалення конструкції друкарського апарату для поліпшення якості друку відбувається за рахунок змін у фарбових системах (виготовлення висо- коякісних та високолініатурних анілоксових валів та застосування камер-ракельної системи подачі фарби);

- друкарський апарат мають значні габарити, оскільки ширина відбитку може сягати до 4,5 м, що $€$ передумовою насичення друкарської секції механізмами, які забезпечують налагодження на величину друкарського тиску, товщину гофрованого картону та суміщення фарб при друці;

- для забезпечення багатофарбового друку, друкарський апарат у вигляді автономних секцій (модулів) встановлюються послідовно у лінію;

- друкарські секції поєднуються у лінію з висікальними та фальцювально-склеювальними секціями і мають високоавтоматизовані системи керування та технічного діагностування.

До експлуатаційних властивостей відносять наступну сукупність властивостей, що обумовлені фізико-механічними характеристиками:

- можливість отримання жорсткого і міцного паковання;

- придатність до друкування, лакування, склеювання, а також обробки при виготовленні розкрою паковання; вості.

- бар'єрні і сенсорні власти-

Аналіз та вивчення машинного технологічного процесу, до якого відноситься флексографічний друк, зводиться до визначення:

- основних параметрів процесу: швидкість, технологічні навантаження, час, необхідний для операцій, температура [6];

- вплив параметрів та характеристик технологічного процесу на якість друку; 

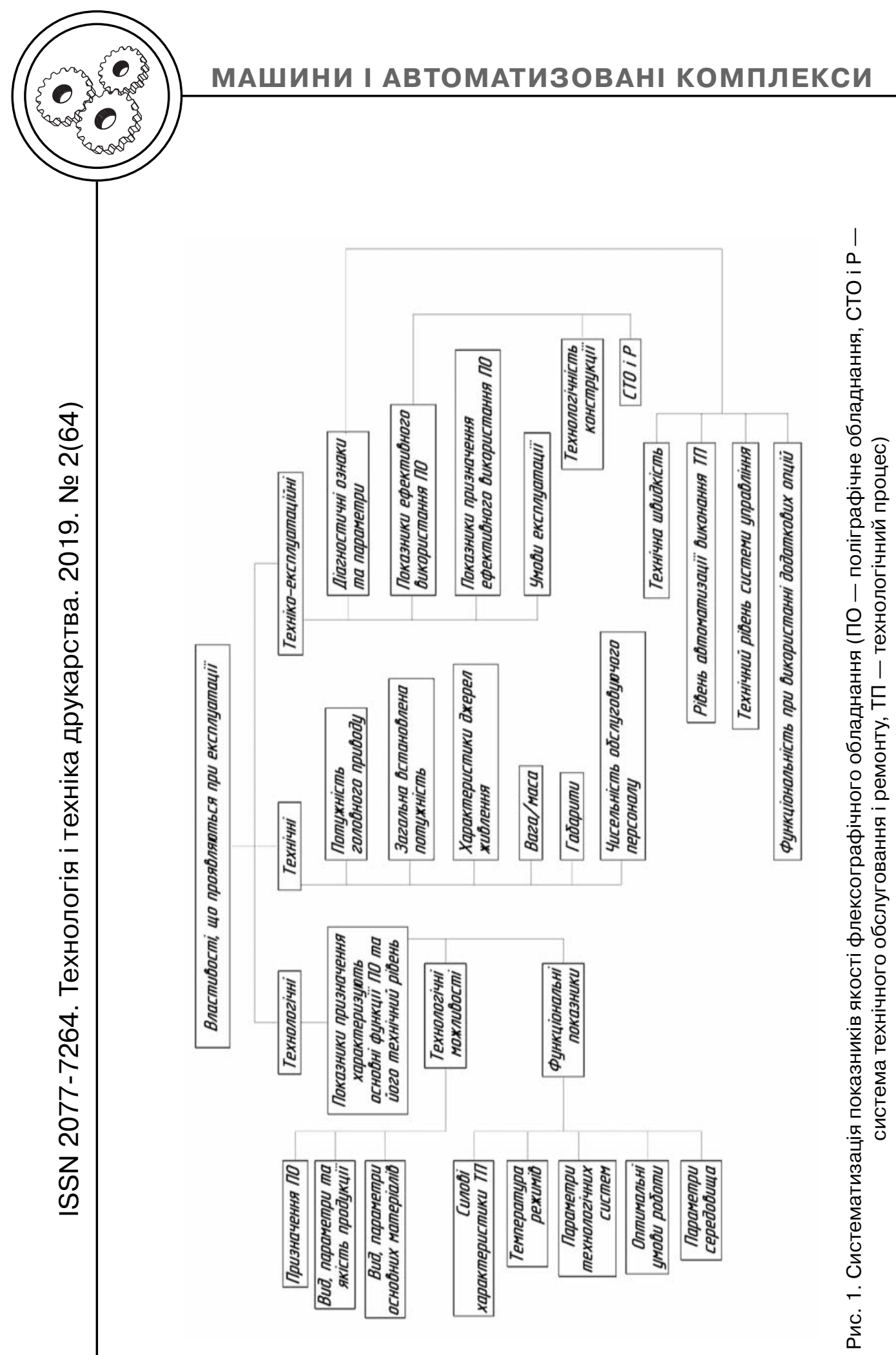
- вплив фізичної та хімічної суті процесу на зміну технічного стану друкарського апарату при його експлуатації.

Флексографічний друк відноситься до способу високого друку, однак його технологічний процес має суттєві відмінності від традиційного типографського способу [7-9]:

- застосування еластичних друкарських форм;

- застосування водорозчинних фарб низької в'язкості;

- невисокий тиск при друці, оскільки друкарські форми виконують функцію носія зображення і одночасно є декелем.

Ці особливості технологічного процесу дозволяють друкувати $з$ невисоким тиском та визначили флексографічний друк основним способом нанесення інформації (тексту, зображення) на паковання $з$ гофрованого картону.

Для отримання якісного відбитка необхідно, щоб у процесі друку баланс між роботою адгезії до поверхні (змочування поверхонь, що контактують) та когезії (розділення фарбового шару) повинен забезпечити розподіл фарбового шару навпіл i не змінюватись протягом друку накладу. Цей процес суттєво залежить від швидкості розділу фарбового шару після спаду напруження та деформаційних властивостей матеріалів у зоні контакту.

Для флексографічного друку величина когезії невелика, оскільки фарби малов'язкі. Оптимальною умовою забезпечення друкарського контакту $\epsilon$ перехід фарби з форми на задруковуваний матеріал в умовах постійного тиску $[6,10,11]$. Однак, є наступні фактори, що негативно впливають на дану умову:

- величина тиску у друкарській парі суттєво залежить від фізико-механічних властивостей гофрованого картону, а саме товщини та шорсткості поверхні, на яку наноситься зображення;

- «цілісність» друкарської форми та її деформаційних властивостей;

- в'язкість фарби змінюється у процесі друку та швидко і доволі часто регулюється вручну.

Це призводить до непостійних і змінних властивостей фарби.

Суттєвим недоліком флексографічного друку є явище розтискування. Його виникнення пов'язане з тим, що друкарський тиск на площині форми неоднаковий, оскільки на ній присутні штрихові, растрові елементи та плашки (рис. 2).

Тому тиск виставляється для якісного друку одного типу елементів, як правило, плашки [12].

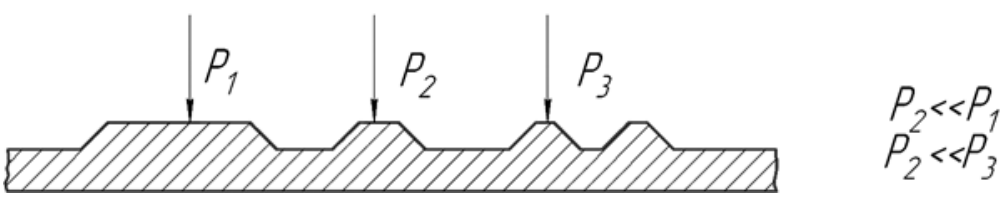

Рис. 2. Друкувальні елементи форми 
Але встановлений тиск деформує найменші друкувальні/ пробільні (залежно від типу форми) елементи, оскільки форма еластична. Взагалі, хоча фарба й переноситься на форму при дуже низькому тиску, проте еластична форма трохи деформується.

\section{Висновки}

У даному дослідженні розглянуто показники якості флексографічного обладнання, їх вплив на проходження технологічних процесів, особливості задруковування заготовок з гофрованого картону. Розглянуто всі елементи, що беруть участь у процесі друку, вплив кожного з них на якісне виконання паковання. Описано технологічні та експлуатаційні властивості флексографічного аркушевого друкарського обладнання, друкарських форм та гофрованого картону, а також їх основні фізико-механічні властивості. Проаналізовано технологічний процес друку на гофрованому картоні на аркушевих флексографічних машинах та визначено фактори, що на нього впливають. Проведено систематизацію показників якості друку на сучасному пакованні з гофрованого картону, що визначають конструктивні особливості побудови друкарських апаратів аркушевих флексографічних друкарських машин.

\section{Список використаної літератури}

1. ГОСТ 15467-79. Управление качеством продукции. Основные показатели. Термины и определения.

2. ГОСТ 4353-90. Система показателей качества продукции. Оборудование полиграфическое. Номенклатура показателей.

3. гОСТ 27.002-89. Надежность в технике. Термины и определения.

4. ГОСТ 4353-85. Система показателей качества продукции. Оборудование полиграфическое. Номенклатура показателей.

5. ГОСТ 2.601-2006. Единая система конструкторской документации. Эксплуатационные документы.

6. Дорош А. К. Контроль якості технологічних процесів та устаткування флексографічного способу друку: монографія / А. К. Дорош, Т. В. Розум. К.: Нац. техн. ун-т України «Київ. політехн. ін-т». 2007. 204 с. Бібліогр.: 147 назв. укр.

7. Киппхан Г. Энциклопедия по печатным средствам информации / Г. Киппхан. М.: МГУП. 2003. 1280 с.

8. Дж. Пейдж Крауч. Основы флексографии / Дж. П. Крауч. М.: МгУП. 2004. 165 c.

9. Техника флексографской печати. Ч. 1: Учебное пособие: Пер. с нем. / Под ред. В. М. Митрофанова, Б. А. Сорокина. М.: МГУП. 2000. 208.

10. Сорокин Б. А. Флексографская печать / Б. А. Сорокин, О. В. Здан. М.: МГАП «Мир книги». 1996. 192 с.

11. Ярема С. М. Флексографія. Обладнання. Технологія: навчальний посібник / С. М. Ярема. К.: Либідь. 1998. 312 с.

12. Кривошей В. М. Упаковка в нашому житті / В. М. Кривошей. К.: ІАЦ «Упаковка». 2001. 160 с.

\section{References}

1. GOST 15467-79. Upravlenie kachestvom produktsii. Osnovnye pokazateli. Terminy i opredeleniya [in Russian]. 
2. GOST 4353-90. Sistema pokazateley kachestva produktsii. Oborudovanie poligraficheskoe. Nomenklatura pokazateley [in Russian].

3. GOST 27.002-89. Nadezhnost' v tekhnike. Terminyi opredeleniya [in Russian].

4. GOST 4353-85. Sistema pokazateley kachestva produktsii. Oborudovanie poligraficheskoe. Nomenklatura pokazateley [in Russian].

5. GOST 2.601-2006. Edinaya sistema konstruktorskoy dokumentatsii. Ekspluatatsionnye dokumenty [in Russian].

6. Dorosh, A. K. \& Rozum, T. V. (2007). Kontrol yakosti tekhnolohichnykh protsesiv ta ustatkuvannia fleksohrafichnoho sposobu druku. Kyiv: Nats. tekhn. unt Ukrainy 'Kyiv. politekhn. in-t', 204 p. [in Ukrainian].

7. Kippkhan, G. (2003). Entsiklopediya po pechatnym sredstvam informatsii. Moscow: MGUP, 1280 p. [in Russian].

8. Krauch, Dzh. Peydzh (2004). Osnovy fleksografii. Moscow: MGUP, 165 p. [in Russian].

9. (2000). Tekhnika fleksografskoy pechati. Ch. 1. Moscow: MGUP, 208 p. [in Russian].

10. Sorokin, B. A. \& Zdan, O. V. (1996). Fleksografskaya pechat'. Moscow: MGAP 'Mir knigi', 192 p. [in Russian].

11. Yarema, S. M. (1998). Fleksohrafiia. Obladnannia. Tekhnolohiia. Kyiv: Lybid, 312 p. [in Ukrainian].

12. Kryvoshei, V. M. (2001). Upakovka v nashomu zhytti. Kyiv: IATs 'Upakovka', 160 p. [in Ukrainian].

Рассматриваются показатели качества флексографских

машин для запечатывания гофрированного картона.

Проанализировано влияние факторов, от которых зависит качество конечной продукции.

Ключевые слова: флексографическая машина;
печатный аппарат; гофрированный картон;
Фотополимерная Форма; плашка; анилоксовый вал.

This article describes the quality of flexographic printing machines for corrugated cardboard printing. The influence of the factors on which the quality of the final product depends is analyzed. Technological properties of printing equipment are characterized by purpose indicators, which determine its technological capabilities, as well as functional indicators, which include the parameters of the technological process and features of its passage. For sheet flexographic printing machines for corrugated cardboard printing, technological possibilities are revealed through the type and parameters of the original production, the nature of consumables. Inturn, they can affect not only the parameters of the process, but also determine the technological scheme of the machine and its components.

Keywords: flexographic press; printing unit; corrugated board; photopolymeric printing plate; tint; anilox.

$$
\begin{array}{r}
\text { Рецензент - О. О. Палюх, канд. техн. наук, } \\
\text { доцент, КПІ ім. Ігоря Сікорського }
\end{array}
$$

